\title{
Distribusi Bakteri Patogen pada Ikan Nila (Oreochromis niloticus) di Danau Batur, Bali
}

\author{
Ni Putu Wiwin Angreni a*, I Wayan Arthana a, Endang Wulandari S. ${ }^{a}$ \\ a Program Studi Manajemen Sumberdaya Perairan, Fakultas Kelautan dan Perikanan, Universitas Udayana, Bukit Jimbaran, \\ Badung, Bali-Indonesia \\ * Penulis koresponden. Tel.: +62-812-461-202-97 \\ Alamat e-mail: wiwinangreni.911@gmail.com \\ Diterima (received) 24 Juli 2018; disetujui (accepted) 15 Agustus 2018
}

\begin{abstract}
This research aims to determine the distribution of pathogen bacteria of Tilapia (Oreochromis nilotics), types of bacteria attacks wild Tilapia and fish in Floating Culture Net (FCN) of Batur Lake as well as its prevalence bacteria found in Tilapia on Batur lake. Method used in this research is descriptive method, with a sampling method based on purposive sampling technique. The distribution of pathogen bacteria of Batur Lake area at station 1 found 2 types of bacteria are Plesiomonas shigelloides and Aeromonas hydrophila at station 2 found 4 types are Aeromonas hydrophila, Aeromonas caviae, Plesiomonas shigelloides and Citrobacter freundii, at station 3 there found 3 types of bacteria are Aeromonas hydrophila, Aeromonas caviae dan Citrobacter freundii. Bacteria that infect wild fish are Aeromonas hydrophila, Aeromonas caviae and Plesiomonas shigelloides, while fishes in FCN are infected by Aeromonas hydrophila, Aeromonas caviae, Plesiomonas shigelloides and Citrobacter freundii bacteria. Infection prevalence of pathogen bacteria in Tilapia in Batur Lake is Aeromonas hydrophila at 55,5\%, Plesiomonas shigelloides for 27,7\%, Aeromonas caviae and Citrobacter freundii at $11,1 \%$. According to sampling location, prevalence of bacteria that attacks wild fish are Aeromonas hydrophila and Plesiomonas shigelloides at $44,4 \%$, Aeromonas caviae for $11,1 \%$. Prevalence of bacteria that attacks fish in FCN is Aeromonas hydrophila for $66,6 \%$, Citrobacter freundii infection at 22,2\%, Aeromonas caviae and Citrobacter freundii at $11,1 \%$.
\end{abstract}

Keywords: Distribution;Tilapia; Bacteria; Prevalence; Batur Lake

\begin{abstract}
Abstrak
Penelitian ini bertujuan untuk mengetahui distribusi bakteri yang menginfeksi ikan nila (Oreochromis niloticus) di kawasan Danau Batur, jenis bakteri yang menginfeksi ikan nila liar dan ikan nila di dalam Karamba Jaring Apung (KJA) di Danau Batur dan bagaimana prevalensi bakteri yang terdapat pada ikan nila di Danau Batur. Metode yang digunakan dalam penelitian ini yaitu metode deskriptif, dengan metode pengambilan sampel berdasarkan teknik purposive sampling. Distribusi bakteri patogen di kawasan Danau Batur yaitu pada stasiun 1 ditemukan 2 jenis bakteri yaitu Plesiomonas shigelloides dan Aeromonas hydrophila, pada stasiun 2 ditemukan 4 jenis yaitu Aeromonas hydrophila, Aeromonas caviae, Plesiomonas shigelloides dan Citrobacter freundii, pada stasiun 3 ditemukan 3 jenis bakteri yaitu Aeromonas hydrophila, Aeromonas caviae dan Citrobacter freundii. Jenis bakteri yang menginfeksi ikan nila liar yaitu Aeromonas hydrophila, Aeromonas caviae dan Plesiomonas shigelloides dan bakteri yang menginfeksi ikan di dalam KJA yaitu Aeromonas hydrophila, Aeromonas caviae, Plesiomonas shigelloides dan Citrobacter freundii. Prevalensi infeksi bakteri patogen pada ikan nila di kawasan Danau Batur adalah Aeromonas hydrophila sebesar 55,5\%, Plesiomonas shigelloides sebesar 27,7\%, Aeromonas Caviae dan Citrobacter freundii sebesar 11,1\%. Berdasarkan lokasi pengambilan sampel prevalensi bakteri yang menyerang ikan liar yaitu Aeromonas hydrophila dan Plesiomonas shigelloides sebesar 44,4\%, Aeromonas caviae sebesar $11,1 \%$. Prevalensi bakteri yang menyerang ikan di KJA yaitu Aeromonas hydrophila sebesar 66,6\%, infeksi Citrobacter freundii sebesar 22,2\%, Aeromonas caviae dan Citrobacter freundii sebesar 11,1\%.
\end{abstract}

Kata Kunci: Distribusi: Ikan Nila; Bakteri; Prevalensi; Danau Batur 


\section{Pendahuluan}

Danau Batur merupakan danau terbesar di Pulau Bali yang terletak di Kecamatan Kintamani, Kabupaten Bangli. Danau tersebut telah dimanfaatkan masyarakat dalam berbagai sektor salah satunya di sektor perikanan. Danau Batur memiliki luas $16,05 \mathrm{~km}^{2}$ dengan kedalaman maksimum sekitar 60-70 m serta berada di ketinggian $1.050 \mathrm{~m}$ di atas permukaan laut (Wijaya et al., 2012). Pada tahun 2011 perairan Danau Batur yang relatif subur ini memberikan gambaran potensi produksi sebesar 98,56-99,48 kg/ha/tahun, dengan rata-rata sebesar 159 ton/tahun (Suryati dan Samuel, (2012) dalam Diarta et al., (2016)). Potensi produksi sumberdaya ikan dapat dihitung berdasarkan kandungan klorofil-a di perairan, berdasarkan asumsi tersebut estimasi potensi produksi sumber daya ikan di Danau Batur menurut (Wijaya et al., 2012) berkisar antara 221,2 $270,3 \mathrm{~kg} / \mathrm{ha} /$ tahun.

Pembangunan infrastruktur dan pemanfaatan perairan danau akan berpengaruh terhadap kondisi kualitas perairan danau. Pencemaran akan menurunkan kualitas perairan yang pada akhirnya akan berpengaruh pula terhadap potensi produksi ikan di Danau Batur, karena ikan dan organisme akuatik lainnya membutuhkan persyaratan habitat yang baik untuk mendukung kehidupannya (Kristanto, 2002). Akibat kualitas air yang menurun dapat menyebabkan meningkatnya pertumbuhan dan perkembangan mikroorganisme dan memunculkan berbagai penyakit pada ikan budidaya yang terdapat di Danau Batur. Sebaran dan distribusi bakteri relatif luas, sehingga dapat ditemukan pada hampir semua wilayah perairan. Distribusi bakteri pada suatu perairan disebabkan oleh beberapa faktor salah satunya yaitu jarak antara daratan dan perairan, iklim, dan organisme lain (Musdalifah, 2013).

Munculnya penyakit ikan akibat serangan bakteri bila tidak ditangani secara dini, akan mengganggu dan menghambat perkembangan usaha tersebut bahkan bisa menyebabkan kematian yang tinggi, yang dapat mengakibatkan terjadinya penurunan produksi. Oleh karena itu informasi mengenai jenis bakteri patogen yang sering menyerang ikan budidaya di daerah Danau Batur sangat diperlukan, agar dapat diambil tindakan pencegahan maupun pengobatan. Penelitian ini bertujuan untuk mengetahui distribusi bakteri patogen yang menyerang ikan nila (Oreochromis niloticus) di Danau Baturge mengetahui jenis bakteri patogen yang menyerang ikan nila di dalam KJA dan ikan nila liar di Danau Batur dan mengetahui prevalensi bakteri yang terdapat pada ikan nila di Danau Batur

\section{Metode Penelitian}

\subsection{Waktu dan Lokasi Penelitian}

Penelitian dilaksanakan pada bulan Februari 2018 di Kawasan Danau Batur, Kecamatan Kintamani, Kabupaten Bangli. Provinsi Bali. Analisa sampel ikan nila dilaksanakan di Laboratorium Balai Karantina Ikan \& Pengendalian Mutu Kelas I Denpasar (BKIPM), dan untuk analisa sampel air dilaksanakan di UPT. Balai Laboratorium Kesehatan Denpasar dan UPT Laboratorium Analitik UNUD. Peta lokasi penelitian dapat dilihat pada Gambar 1.

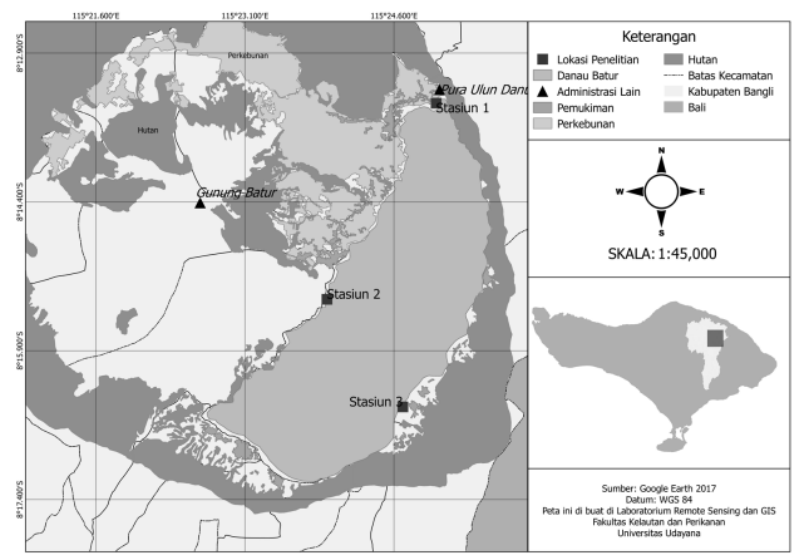

\section{Gambar 1. Peta Lokasi Penelitian}

\subsection{Alat dan Bahan}

Alat yang digunakan dalam penelitian ini adalah sectio set, gelas ukur, erlenmeyer, cawan petri, beaker glass, jarum ose, bunsen. Bahan yang digunakan dalam penelitian ini adalah ikan nila yang berasal dari Danau Batur. Media yang digunakan untuk isolasi bakteri adalah media TSA (Triptic Soy Agar). Sedangkan bahan untuk uji biokimia adalah OF, Citrate, Nitrat, SIM (Sulfid Indol Motility), Indol, Gelatin, Urea, MRVP, TSIA (Triple Sugar Iron Agar), Glukosa dan Akuades.

\subsection{Pengambilan Data}


Metode yang digunakan dalam penelitian ini yaitu metode deskriptif, dengan metode pengambilan sampel berdasarkan teknik purposive sampling. Pengambilan data kualitas air sebagai data pendukung dilakukan bersamaan dengan pengambilan sampel ikan nila. Pengambilan sampel ikan dilakukan satu kali pengambilan di lapangan.

\subsubsection{Pengambilan Sampel Ikan}

Pengambilan sampel ikan dilakukan pada 3 stasiun yang berbeda yaitu (Stasiun 1) kawasan Desa Songan, (Stasiun 2) kawasan Desa Batur dan (Stasiun 3) kawasan Desa Abang. Pada tiap stasiun terdiri dari 2 titik pengambilan sampel yaitu ikan nila yang diambil di luar KJA (ikan liar) dan ikan nila yang diambil dari dalam KJA . Jumlah sampel ikan nila yang diambil di KJA dan dari nelayan masing-masing sebanyak 3 ekor dalam kondisi hidup, sehingga jumlah total sampel sebanyak 18 ekor. Sampel ikan nila dibawa ke Laboratorium Ilmu Perikanan Fakultas Kelautan dan Perikanan untuk selanjutnya dianalisa bakteri di BKIPM.

\subsubsection{Pembedahan dan Isolasi}

Organ target uji berupa hati dan ginjal diambil dengan cara membedah bagian perut ikan nila Isolasi bakteri ini dilakukan dengan menggunakan media umum TSA. Isolasi bakteri dilakukan secara aseptik di Laminar air flow dengan teknik cawan gores, yaitu dengan menusukkan jarum ose yang steril ke organ ikan yaitu hati dan ginjal.

\subsubsection{Pemurnian}

Pemurnian dilakukan dengan mengamati koloni bakteri yang tumbuh terpisah di dalam gores dan koloni bakteri yang dominan diambil menggunakan jarum ose selanjutnya dimurnikan kembali pada media TSA. Apabila hasil pemurnian diperoleh koloni yang seragam maka diteruskan dengan uji lanjutan yaitu uji presumtif dan uji biokimia.

\subsubsection{Uji Presumtif dan Uji Biokimia}

Uji Presumtif terdiri dari tahapan uji gram, uji katalase, dan uji oksidase, sedangkan Uji Biokimia meliputi uji OF, uji Simon Citrat, uji Nitrat, uji SIM, uji Nutrien Gelatin, uji Urea, uji MR VP, uji TSIA, dan uji Karbohidrat Base.

\subsubsection{Pengukuran Kualitas Air}

Pengambilan parameter kualitas air bersamaan dengan pengambilan sampel ikan. Parameter kualitas air yang diukur meliputi suhu, oksigen terlarut, derajat keasaman $(\mathrm{pH})$, kecerahan dan amoniak. Pengukuran suhu, $\mathrm{pH}, \mathrm{DO}$ dan kecerahan dilakukan secara in situ di lokasi pengambilan sampel, untuk pengukuran amoniak, BOD dan COD dianalisis di UPT. Balai Laboratorium Kesehatan Denpasar. Sedangkan pengukuran TOM dilakukan pada UPT. Laboratorium Analitik UNUD.

\subsection{Analisis Data}

Bakteri yang teridentifikasi dicatat jenis dan tempat organ ditemukan, serta menghitung prevalensi. Rumus prevalensi sebagai berikut:

Prevalensi $=\frac{\text { Jumlah Ikan yang terinfeksi }}{\text { Jumlah sampel ikan yang diperiksa }} \times 100 \%$

\section{Hasil dan Pembahasan}

\subsection{Distribusi Bakteri Patogen di Kawasan Danau Batur}

Distribusi bakteri patogen di kawasan Danau Batur pada stasiun 1 kawasan Desa Songan ditemukan 2 jenis bakteri yaitu bakteri Plesiomonas shigelloides yang menginfeksi ikan liar dan bakteri Aeromonas hydrophila yang menginfeksi ikan di dalam KJA. Pada stasiun 2 kawasan Desa Batur ditemukan 3 jenis bakteri yang menginfeksi ikan liar yaitu Plesiomonas shigelloides, Aeromonas hydrophila, dan Aeromonas caviae sedangkan bakteri yang menginfeksi ikan di KJA terdapat 3 jenis yaitu Plesiomonas shigelloides, Aeromonas hydrophila dan Citrobacter freundii. Pada stasiun 3 kawasan Desa Abang ditemukan 1 jenis bakteri yang menginfeksi ikan liar yaitu bakteri Aeromonas hydrophila, sedangkan pada ikan di KJA ditemukan 3 jenis bakteri yaitu Aeromonas hydrophila, Citrobacter freundii dan Aeromonas caviae Berdasarkan hasil identifikasi ditemukan 4 jenis bakteri yang menginfeksi ikan di kawasan Danau Batur diantaranya Aeromonas hydrophila, Aeromonas caviae, Plesiomonas shigelloides dan Citrobacter freundii. 


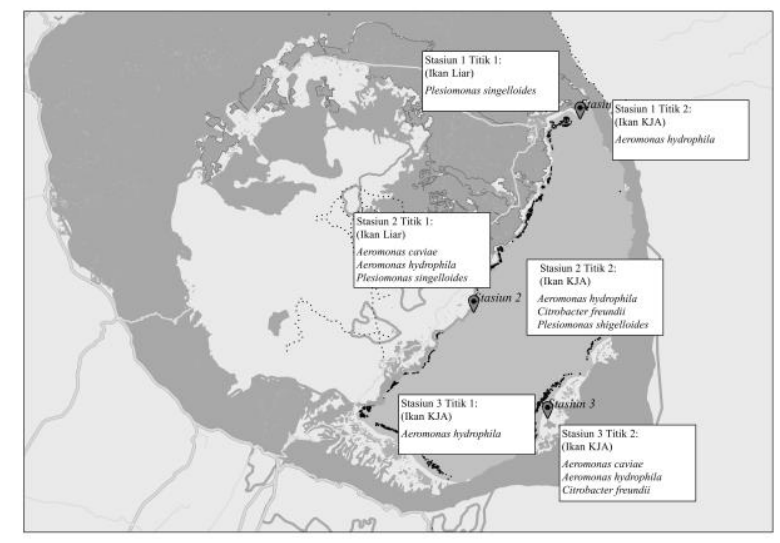

Gambar 2. Distribusi Jenis Bakteri yang Ditemukan di semua stasiun

Jenis bakteri yang menginfeksi ikan liar adalah bakteri Aeromonas hydrophila, Aeromonas caviae dan Plesiomonas shigelloides, sedangkan bakteri yang menginfeksi ikan di KJA yaitu bakteri Aeromonas hydrophila, Aeromonas caviae, Plesiomonas shigelloides dan Citrobacter freundii, Ikan yang terserang penyakit bakteri disebabkan karena faktor dari luar (lingkungan) dan dari dalam ikan itu sendiri. Infeksi yang menyebar dapat disebabkan oleh kerentanan ikan yang dipengaruhi kondisi lingkungan yang buruk (Harris et al., 2000). Faktor yang mempengaruhi tersebut antara lain adanya patogen, stres, kepadatan ikan yang terlalu tinggi, limbah rumah tangga, limbah pertanian, sisa pakan pada budidaya dan musim. Hal tersebut sesuai dengan pernyataan Novriadi et al., (2014), penyakit pada ikan umumnya timbul akibat tidak seimbangnya tiga faktor, yang meliputi inang, patogen dan lingkungan. Kualitas air yang buruk, pemberian pakan ikan yang berlebih dan perubahan iklim juga merupakan faktor penyebab timbulnya penyakit (Azmi et al., 2013). Penurunan kualitas air danau menyebabkan menurunnya kondisi kesehatan ikan yang dibudidayakan dan memungkinkan berkembangnya bakteri heterotrofik dan bakteri patogen pada perairan budidaya (Badjoeri, 2008).

Prevalensi ikan tertinggi terdapat pada 2 stasiun di kawasan Danau Batur yaitu pada stasiun 2 dan stasiun 3. Pada stasiun 2 baik pada ikan liar maupun ikan di dalam KJA nilai prevalensi sebesar $100 \%$. Hal ini diduga karena lokasi pengambilan sampel ikan yang berdekatan dengan rumah penduduk serta kegiatan pertanian yang menyebabkan kondisi lingkungan yang buruk sehingga ikan nila yang berada di kawasan Desa Batur terinfeksi bakteri yang banyak. Hal tersebut sesuai dengan pernyataan Maulana et al.,
(2017) tinggi rendahnya nilai prevalensi pada setiap lokasi pengambilan sampel ikan dipengaruhi oleh faktor antara lain parameter kualitas air, yang diakibatkan oleh pencemaran di sekitar perairan baik limbah rumah tangga maupun limbah pertanian.

Tabel 2

Distribusi Bakteri dan Prevalensi Ikan yang Terinfeksi Bakteri Patogen di Kawasan Danau Batur

\begin{tabular}{|c|c|c|}
\hline $\begin{array}{c}\text { Lokasi Pengambilan } \\
\text { Sampel } \\
\end{array}$ & Jenis Bakteri & Prevalensi \\
\hline \multicolumn{3}{|l|}{$\begin{array}{l}\text { Stasiun1 } \\
\text { (Desa Songan) }\end{array}$} \\
\hline \multirow{2}{*}{ S 1.1 Ikan Liar } & Plesiomonas shingeloides & $66,6 \%$ \\
\hline & Plesiomonas shingeloides & \\
\hline \multirow[t]{3}{*}{ S 1.2 Ikan KJA } & Aeromonas hydrophila & $66,6 \%$ \\
\hline & Aeromonas hydrophila & \\
\hline & Aeromonas hydrophila & \\
\hline \multicolumn{3}{|l|}{$\begin{array}{l}\text { Stasiun } 2 \\
\text { (Desa Batur) }\end{array}$} \\
\hline \multirow[t]{4}{*}{ S 2.1 Ikan Liar } & Plesiomonas shingeloides & $100 \%$ \\
\hline & Aeromonas hydrophila & \\
\hline & Plesiomonas shingeloides & \\
\hline & Aeromonas caviae & \\
\hline \multirow[t]{4}{*}{ S 2.2 Ikan KJA } & Aeromonas hydrophila & $100 \%$ \\
\hline & Aeromonas hydrophila & \\
\hline & Plesiomonas shingeloides & \\
\hline & Citrobacter freundii & \\
\hline \multicolumn{3}{|l|}{$\begin{array}{l}\text { Stasiun } 3 \\
\text { (Desa Abang) }\end{array}$} \\
\hline \multirow[t]{3}{*}{ S 3.1 Ikan Liar } & Aeromonas hydrophila & $100 \%$ \\
\hline & Aeromonas hydrophila & \\
\hline & Aeromonas hydrophila & \\
\hline \multirow[t]{3}{*}{ S 3.2 Ikan KJA } & Aeromonas hydrophila & $66,6 \%$ \\
\hline & Citrobacter freundii & \\
\hline & Aeromonas caviae & \\
\hline
\end{tabular}

Selanjutnya pada stasiun 3 kawasan Desa Abang pada ikan di dalam KJA prevalensi sebesar 100\%. Hal ini diduga karena pada kawasan Desa Abang terdapat KJA dengan jumlah paling banyak sehingga limbah budidaya yang berasal dari sisa pakan dan feses ikan dapat mencemari perairan. Sedangkan prevalensi ikan yang terinfeksi bakteri patogen terendah yaitu pada stasiun 1 kawasan Desa Songan sebesar $66,6 \%$ baik pada ikan liar maupun ikan di dalam KJA dan stasiun 3 kawasan Desa Abang pada ikan liar sebesar 66,6\%. Menurut Putri et al., (2016) kondisi lingkungan dalam perairan dapat mempengaruhi prevalensi, karena dengan kondisi lingkungan yang buruk akan 
mengakibatkan kondisi ikan tersebut lemah sehingga patogen lebih mudah menyerang. Menurut Badjoeri (2013) sebaran bakteri berinteraksi kuat dengan faktor lingkungan habitatnya yang dicirikan dengan kandungan DO, $\mathrm{pH}$ dan bahan organik (TOM) yang tinggi.

\subsection{Prevalensi Infeksi Bakteri Patogen}

Prevalensi infeksi bakteri patogen tertinggi pada ikan nila di kawasan Danau Batur adalah infeksi bakteri Aeromonas hydrophila sebesar 55,5\%. Menurut Cipriano (2001) dalam Ashari et al., (2014) Aeromonas hydrophila merupakan bakteri yang umum terdapat di habitat air tawar dan bakteri ini sering menyebabkan penyakit pada ikan budidaya. Hal ini sesuai dengan penelitian yang dilakukan oleh Manurung dan Susantie (2017), yang membuktikan bakteri Aeromonas hydrophila merupakan bakteri yang paling banyak ditemukan menginfeksi ikan nila. Bakteri Aeromonas hydrophila ditemukan pada semua stasiun di kawasan Danau Batur. Penelitian yang dilakukan oleh Ashari et al. (2014) di Danau Tondano juga ditemukan bakteri Aeromonas hydrophila yang menginfeksi ikan nila.

Prevalensi infeksi bakteri tertinggi kedua adalah infeksi bakteri Plesiomonas shigelloides sebesar 27,7\%. Bakteri Plesiomonas shigelloides ditemukan pada 2 stasiun yaitu stasiun 1 kawasan Desa Songan pada ikan liar dan stasiun 2 kawasan Desa Batur pada ikan liar dan ikan di dalam KJA. Bakteri Plesiomonas shigelloides adalah patogen yang muncul yang tersebar luas di lingkungan akuatik, distribusi alami mikroorganisme ini adalah air dan ikan di daerah beriklim tropis (Miller et al., 2006). Dalam kestabilan ekologi kolam, pertumbuhan terbesar Plesiomonas sp. ditemukan dalam lumpur dan toleran terhadap pH tinggi (Ashari et al., 2014).

Prevalensi Infeksi bakteri terendah yaitu Aeromonas Caviae dan Citrobacter freundii sebesar 11,1\%. Bakteri Aeromonas caviae hanya ditemukan pada 2 stasiun yaitu pada stasiun 2 kawasan Desa Batur yaitu pada ikan liar dan pada stasiun 3 kawasan Desa Abang yaitu pada ikan di dalam KJA. Distribusi Aeromonas spp. dalam lingkungan akuatik secara signifikan terkait dengan tingkat pencemaran air. Bakteri Aeromonas caviae terdapat pada air dengan tingkat polusi feses dan kotoran yang tinggi, namun dalam air yang kurang tercemar Aeromonas caviae hampir terdistribusi merata (Abulhamd, 2009). Faktor yang mempengaruhi distribusi penyebaran luas bakteri Aeromonas caviae di lingkungan budidaya ikan air tawar seperti kekeruhan, PH, salinitas dan suhu air (Miranda dan Castillo 1996).

Bakteri Citrobacter freundii ditemukan pada 2 stasiun yaitu stasiun 2 kawasan Desa Batur pada ikan di dalam KJA dan stasiun 3 kawasan Desa Abang pada ikan di dalam KJA. Citrobacter freundii merupakan spesies Enterobactericeae, yang sering ditemukan di air, tanah, makanan, kotoran dan saluran pencernaan pada manusia dan hewan. Citrobacter freundii dapat menyebabkan lesio pada kulit, sirip, insang dan organ internal serta haemorrhagic dan infeksi Citrobacter freundii pada ikan nila menunjukkan gejala haemorrhagi septikemia akut (Svetlana et al., 2003).

Penelitian ini berbeda dengan penelitian yang dilakukan oleh Handayani (2012) dalam penelitian tersebut prevalensi bakteri yang menyerang ikan air tawar tertinggi yaitu prevalensi infeksi bakteri Plesiomonas shigelloides sebesar 26,8\%, Aeromonas Caviae sebesar 8,13\%, Aeromonas hydrophilla sebesar 7,50\% dan Citrobacter freundii sebesar 5,00\%.

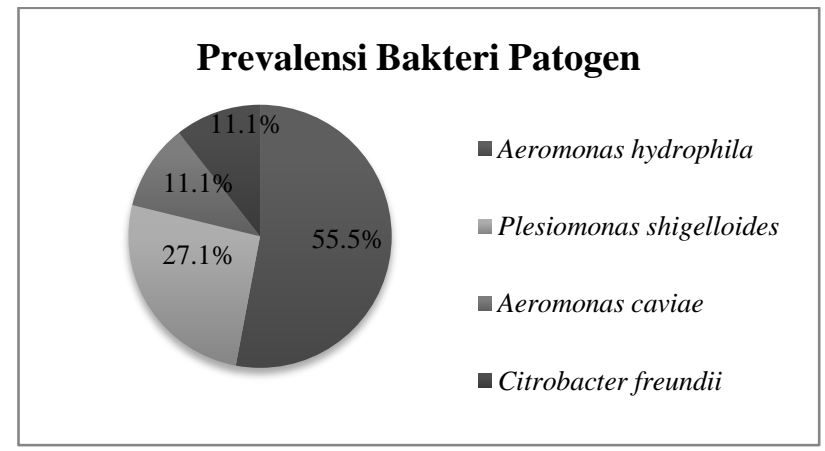

Gambar 3. Prevalensi Bakteri Patogen

\subsection{Prevalensi Infeksi Bakteri Berdasarkan Lokasi Pengambilan Sampel}

Berdasarkan hasil pengamatan menunjukan ikan yang berada di dalam KJA terinfeksi bakteri dengan jenis yang lebih banyak dari ikan liar. Terdapat 4 jenis bakteri yang menginfeksi ikan di dalam KJA yaitu Aeromonas hydrophila dengan prevalensi sebesar $66.6 \%$, Aeromonas caviae sebesar $11,1 \%$, Plesiomonas shigelloides sebesar 11,1\% dan Citrobacter freundii sebesar 22,2\%. Hal ini diduga karena tingginya kepadatan ikan di dalam KJA yang menyebabkan ruang gerak terbatas. Kepadatan ikan yang tinggi dapat menyebabkan ikan menjadi stres sehingga dapat menurunkan daya tahan tubuh ikan tersebut dan akhirnya memberi ruang yang bebas bagi bakteri untuk 
menyerang dan menyebabkan ikan sakit. Hal ini sesuai dengan Fitratunisa (2016) stres diakibatkan oleh kondisi lingkungan buruk serta ditunjang oleh keberadaan patogen seperti bakteri menyebabkan penyakit akan mudah menginfeksi ikan. Menurut Handayani (2012) pada lingkungan budidaya, faktor stres seperti jumlah populasi yang padat, kualitas air yang buruk, cedera fisik akibat proses penanganan yang kurang tepat (penangkapan, penyortiran dan transportasi) dapat mengakibatkan kerentanan atau melemahnya pertahanan ikan yang berpotensi mempermudah masuk dan menyebarnya bakteri dan agen penyakit lainnya ke tubuh ikan.

Tabel 3.

Prevalensi Bakteri Berdasarkan Lokasi

\begin{tabular}{lcc}
\hline $\begin{array}{c}\text { Lokasi Pengambilan } \\
\text { Sampel }\end{array}$ & Jenis Bakteri & $\begin{array}{c}\text { Prevalensi } \\
\%\end{array}$ \\
\hline Ikan Liar & Aeromonas hydrophila & 44,4 \\
S 1.1, S 2.1, S 3.1 & Aeromonas Caviae & 11,1 \\
& Plesiomonas singeloides & 44,4 \\
& Citrobacter freundii & -
\end{tabular}

\begin{tabular}{lcc} 
Ikan di Dalam KJA & Aeromonas hydrophila & 66,6 \\
S 1.2, S 2.2, S 3.2 & Aeromonas Caviae & 11,1 \\
& Plesiomonas singeloides & 11,1 \\
& Citrobacter freundii & 22,2 \\
\hline
\end{tabular}

Jenis bakteri yang menginfeksi ikan liar lebih sedikit dari ikan di dalam KJA. Bakteri yang menginfeksi ikan liar sebanyak 3 jenis yaitu bakteri Aeromonas hydrophila dengan prevalensi sebesar 44,4\%, Aeromonas caviae sebesar 11,1 dan Plesiomonas shigelloides $44,4 \%$. Tingginya prevalensi bakteri Plesiomonas shigelloides yang menginfeksi ikan liar diduga disebabkan dari kondisi lingkungan perairan pada stasiun kawasan luar yang memiliki kandungan bahan organik yang lebih tinggi. Hal ini terlihat dari hasil analisa kandungan bahan organik total pada kawasan Desa Songan luar sebesar $8.5004 \mathrm{mg} / \mathrm{l}$ dan pada kawasan Desa Batur luar sebesar 10.5404 mg/l. Menurut Arfianto dan Liviawaty (1992) pertumbuhan Plesiomonas sp. di air tawar tergantung pada suhu, ketersediaan hara, dan tingkat cemaran limbah di dalam perairan. Ikan liar lebih sedikit terinfeksi bakteri diduga karena ikan liar lebih memiliki ruang gerak yang lebih luas dan tidak terpengaruh dengan stres akibat kepadatan. Faktor ikan liar terserang bakteri diduga karena kondisi lingkungan sekitar yang buruk dengan adanya pencemaran perairan seperti limbah rumah tangga, limbah pertanian, limbah peternakan dan limbah budidaya yang menyebabkan kondisi lingkungan perairan sekitar menjadi buruk dan menyebabkan ikan lebih rentan terserang bakteri. Semua ikan rentan terhadap infeksi bakteri yang dapat mengakibatkan terjangkitnya penyakit dan tingkat kematian yang tinggi, baik itu pada spesies liar maupun budidaya (Frerichs dan Millar, 1993).

\subsection{Kualitas Air}

Kondisi nilai suhu pada perairan Danau Batur berkisar antara $24-27^{\circ} \mathrm{C}$. Perbedaan suhu pada lokasi pengukuran di perairan Danau Batur cenderung stabil dengan nilai $27^{\circ} \mathrm{C}$. Menurut Mulqan et al., (2017) suhu optimum untuk pertumbuhan ikan adalah $25-32{ }^{\circ} \mathrm{C}$. Perbedaan suhu tersebut diduga karena adanya selisih waktu pengukuran in situ terhadap pengukuran suhu.

Hasil yang diperoleh dari pengukuran DO air, dapat dijelaskan bahwa nilai DO air pada masingmasing stasiun penelitian memperlihatkan variasi nilai DO yang berbeda disetiap stasiun dengan kisaran nilai 5,4-9,6 mg/l. Nilai DO tertinggi ditemukan pada stasiun 3 kawasan Desa Abang Luar sebesar $9.6 \mathrm{mg} / \mathrm{l}$ sedangkan nilai DO terendah ditemukan pada stasiun 2 kawasan Desa Batur luar dan KJA sebesar 5,4 mg/l. Menurut Nugroho et al., (2013), bahwa kandungan oksigen terlarut dalam media budidaya ikan harus lebih tinggi dari $3,0 \mathrm{mg} / \mathrm{L}$.

Hasil pengukuran $\mathrm{pH}$ pada perairan Danau Batur berkisar antara 7,3-9,41 dimana ikan dapat tumbuh dengan baik pada kisaran $\mathrm{pH}$ 6.5-9 (Nugroho et al., 2013). Kondisi pH di Danau Batur cenderung bersifat alkali atau basa dengan nilai $\mathrm{pH}$ air tertinggi ditemukan pada stasiun 1 kawasan Songan KJA sebesar 9,41 dan nilai $\mathrm{pH}$ terendah ditemukan pada stasiun 1 kawasan Songan luar dan stasiun 2 kawasan Batur Luar yaitu sebesar 7,3 .

Hasil pengukuran kecerahan didapatkan nilai kecerahan yang bervariasi pada setiap stasiun pengukuran dengan nilai $75-192,5 \mathrm{~cm}$. Dimana nilai kecerahan tertinggi berada pada stasiun 1 kawasan Songan KJA sebesar 192,5 cm dan nilai kecerahan terendah terdapat pada stasiun 3 kawasan Abang Luar sebesar $75 \mathrm{~cm}$. Kecerahan di perairan dapat juga dipengaruhi oleh bahan-bahan halus yang melayang-layang dalam air seperti 
plankton, detritus, jasad renik, lumpur dan pasir (Astuti et al., 2016).

Berdasarkan hasil pengukuran selama penelitian didapatkan hasil kandungan amonia tertinggi ditemukan pada stasiun 1 kawasan Desa Songan Luar yaitu sebesar $0,178 \mathrm{mg} / \mathrm{L}$ dan kandungan amonia terendah ditemukan pada stasiun 3 kawasan Desa Abang luar yaitu sebesar 0,012 mg/L. Menurut baku mutu kualitas air PP No. 82 Tahun 2001 (kelas II) bahwa batas maksimum amoniak untuk kegiatan perikanan bagi ikan yang peka $\leq 0,02 \mathrm{mg} / \mathrm{l}$.

Hasil yang diperoleh dari pengukuran nilai BOD tertinggi ditemukan pada stasiun 1 kawasan Songan Luar sebesar $4,78 \mathrm{mg} / \mathrm{l}$ dan nilai BOD terendah ditemukan pada stasiun 3 kawasan Desa Abang KJA sebesar 1,51 mg/l. Nilai ini melebihi baku mutu Peraturan Pemerintah No. 82 Tahun 2001 dimana nilai standar optimum BOD adalah 3 $\mathrm{mg} / \mathrm{l}$.

Hasil yang diperoleh dari pengukuran rata-rata COD antar lokasi berada pada kisaran 9,92-49,00 $\mathrm{mg} / \mathrm{l}$, nilai ini melebihi baku mutu Peraturan Pemerintah No. 82 Tahun 2001 nilai COD adalah $25 \mathrm{mg} / \mathrm{l}$. Nilai COD air tertinggi ditemukan pada stasiun 2 kawasan Desa Batur Luar sebesar 49,00 $\mathrm{mg} / \mathrm{l}$ dan nilai COD terendah ditemukan pada stasiun 3 kawasan Desa Abang Luar sebesar 9,92 $\mathrm{mg} / \mathrm{l}$.

Hasil yang diperoleh dari pengukuran nilai TOM selama penelitian didapatkan nilai TOM tertinggi ditemukan pada stasiun 3 kawasan Abang KJA sebesar 10,9462 mg/l dan nilai TOM terendah ditemukan pada stasiun 1 kawasan Songan KJA sebesar 7,5492 mg/l. Menurut Ulqodry et al., (2010) bahan-bahan organik total secara alamiah berasal dari perairan itu sendiri melalui proses-proses penguraian pelapukan ataupun dekomposisi buangan limbah baik limbah daratan seperti domestik, industri, pertanian, dan limbah peternakan ataupun sisa pakan yang dengan adanya bakteri terurai menjadi zat hara.

\section{Simpulan}

Distribusi bakteri patogen di kawasan Danau Batur yaitu pada stasiun 1 ditemukan 2 jenis bakteri yaitu Plesiomonas shigelloides dan Aeromonas hydrophila, pada stasiun 2 ditemukan 4 jenis yaitu Aeromonas hydrophila, Aeromonas caviae, Plesiomonas shigelloides dan Citrobacter freundii, pada stasiun 3 ditemukan 3 jenis bakteri yaitu Aeromonas hydrophila, Aeromonas caviae dan Citrobacter. Jenis bakteri yang menginfeksi ikan liar adalah bakteri Aeromonas hydrophila, Aeromonas caviae dan Plesiomonas shigelloides, sedangkan bakteri yang menginfeksi ikan di KJA yaitu bakteri Aeromonas hydrophila, Aeromonas caviae, Plesiomonas shigelloides dan Citrocabter freundii. Prevalensi infeksi bakteri patogen tertinggi pada ikan nila di kawasan Danau Batur adalah infeksi bakteri Aeromonas hydrophila yaitu sebesar 55,5\%. Prevalensi infeksi bakteri tertinggi kedua adalah infeksi bakteri Plesiomonas shigelloides sebesar $27,7 \%$. Sedangkan prevalensi Infeksi bakteri terendah yaitu Aeromonas caviae dan Citrobacter freundii sebesar $11,1 \%$.

\section{Saran}

Saran dari penulis adalah, perlu dilakukan penelitian lanjutan mengenai jenis bakteri pada ikan nila pada kawasan lainnya dan jenis ikan lainnya yang terdapat di Kawasan Danau batur, mengingat penelitian ini hanya dilakukan pada 3 lokasi (Desa Songan, Desa Batur dan Desa Abang). Maka diharapkan penelitian ini dapat menjadi acuan dalam penelitian selanjutnya.

\section{Ucapan terimakasih}

Penulis mengucapkan terimakasih kepata BKIPM Kelas 1 Denpasar yang telah mengijinkan untuk melakukan penelitian disana. Terimakasih kepada pembimbing yang telah membimbing penulis selama ini. Terimakasih kepada $\mathrm{Ni}$ Wayan Ernawati, I Wayan Juliawan dan I Gede Bayu Sulastika yang selalu mendampingi dan membantu pada saat penelitian.

\section{Daftar Pustaka}

Abulhamd, A. T. (2009). Characterization of Aeromonas hydrophila isolated from aquatic environment using phenotypic and genotyping methods. Res. J. Agri. and Biolog. Sci., 5(6), 923- 931.

Arfianto, E., \& Liviawaty. (1992). Pengendalian hama dan penyakit ikan. Yogyakarta, Indonesia: Kanisius.

Ashari, C., Tumbol, R. A., \& Kolopita, M. E. F. (2014). Diagnosa penyakit bakterial pada Ikan Nila (Oreocrhomis niloticus) yang di budidaya pada jaring tancap di Danau Tondano. Budidaya Perairan, 2(3), 24-30.

Astuti, M. Y., Damai, A. A., \& Supono. (2016). Evaluasi kesesuaian perairan untuk budidaya Ikan Nila (Oreochromis niloticus) di kawasan pesisir 
Desakandang Besi Kecamatan Kota Agung Barat Kabupaten Tanggamus. e-Jurnal Rekayasa dan Teknologi Budidaya Perairan, V(1), 621-630.

Azmi, H. D. R, Indriyanti, \& Kariada, N. (2013). Identifikasi ektoparasit pada ikan koi (Cyprinus carpio L) di pasar ikan hias Jurnatan Semarang. Unnes J. Life Sci., 2 (2), 64-70.

Badjoeri, M. (2008). Identifikasi bakteri patogen pada sistem karamba jaring apung (KJA) di Danau Maninjau, Sumatera Barat. Oseaonologi dan Limnologi di Indonesia, 34(2), 169-184.

Badjoeri, M. (2013). Distribusi Spasial Bakteri Perombak Nitrogen di Perairan Danau Toba, Sumatra Utara. LIMNOTEK, 20(1), 89-99.

Diarta, I. M., L. K. Merawati., \& P. Y. Pramandari. 2016. Model Optimal Usaha Pembesaran Ikan Nila Sistem Keramba Jaring Apung di Danau Batur Kecamatan Kintamani Kabupaten Bangli. Prosiding Seminar Nasional Lembaga Penelitian dan Pengabdian Masyarakat (LPPM) UNMAS Denpasar 2016. Denpasar.

Fitratunisa. (2016). Inventarisasi penyakit bakteri dan virus pada benih ikan kakap putih Lates calcarifer, bloch 1790 di Balai Besar Perikanan Budidaya Laut (BBPBL) Lampung. Skripsi. Bogor, Indonesia: Departemen Budidaya Perairan, Fakultas Perikanan dan Ilmu Kelautan, Institut Pertanian Bogor.

Frerichs, G. N., \& Millar, S. D. (1993). Manual for the Isolation and Identification of Fish Bacterial Pathogens. Skotlandia: Pisces Press- University of Stirling.

Handayani, E. (2012). Pravalensi Infeksi Bakteri Patogen Pada Ikan Patin (Pangasius hypophthalmus) di Kawasan Minapolitan Kabupaten Banjar. Skripsi. Bogor, Indonesia: Institut Pertanian Bogor.

Harris, P.D., Soleng, A., \& Bakke, T.A. (2000). Increased Suscepbility of Salmonids to the Monogenean Gyrodactylus salaries Following Administration of Hydrocortisone Acetate. Parasitology, 120, 57-64.

Kristanto, P. (2002). Ekologi Industri. Yogyakarta, Indonesia: Penerbit Andi.

Manurung, U. N., \& Susantie, D. (2017). Identifikasi bakteri patogen pada ikan Nila (Oreochromis niloticus) di lokasi budidaya ikan air tawar Kabupaten Kepulauan Sangihe. Budidaya Perairan, 5(3), 11-17.

Maulana, D. M., Muchlisin, Z. A., \& Sugito, S. (2017). Intensitas dan prevalensi parasit pada ikan betok (Anabas testudineus) dari perairan umum daratan
Aceh Bagian Utara. Jurnal Ilmiah Mahasiswa Kelautan dan Perikanan Unsyiah, 2(1), 1-11.

Miller, W. A., Miller, M. A., Gardner, I. A., Atwill, E. R., \& Byrne, B. A. (2006). Salmonella spp., Vibrio spp., Clostridium perfringens, and Plesiomonas shigelloides in marine and freshwater invertebrates from coastal California ecosystems. Microb. Ecol., 52, 198-206.

Miranda, C. D., \& Castillo, G. (1996). Isolation and characterization of Aeromonads isolated from Chilean freshwater and their potential use as water quality indicators. Environ. Toxi. and Water Quality, 11, 91-98.

Mulqan, M., Rahmimi, S. A. E., \& Dewianti, I. (2017). Pertumbuhan dan Kelangsungan Hidup Benih Ikan Nila Gesit (Oreochromis niloticus) Pada Sistem Akuaponik Dengan Jenis Tanaman Yang Berbeda. Jurnal Ilmiah Mahasiswa Kealutan dan Perikanan Unsyiah, 2(1), 183-192.

Musdalifah. (2013). Distribusi dan Kelimpahan Bakteri Enterococcus spp. Di Perairan Terumbu Karang Kepulauan Sprermonde, Makasar. Skripsi. Makasar, Indonesia: Universitas Hasanuddin.

Novriadi, R., Agustatik S., Hendrianto, R., Pramuanggit, \& Wibowo A. H. (2014). Penyakit Infeksi pada Budidaya Ikan Laut di Indonesia. Batam, Indonesia: Balai Perikanan Budidaya Laut Batam.

Nugroho, A., Arini, E., \& Elfitasari, T. (2013). Pengaruh kepadatan yang berbeda terhadap kelulushidupan dan pertumbuhan Ikan Nila (Oreochromis niloticus) pada sistem resirkulasi dengan filter arang. Journal of Aquaculture Management and Technology, 2(3), 94-100.

Putri, S. M., Haditomo, A. H. C., \& Desrina. (2016). Infestasi Monogenea pada ikan konsumsi air tawar di kolam budidaya Desa Ngrajek Magelang. Journal of Aquaculture Management and Technology, 5(1), 162170.

Svetlana, J., Dobrila, J. D., \& Veljovic. (2003). Citrobacter freundii as a cause of Disease in Fish. Acta Veterinaria (Beograd). 53, 5-6.

Ulqodry, T. Z., Yulisman, Muhammad, S., \& Santoso. (2010). Karakteristik dan Sebaran Nitrat, Fosfat dan Oksigen Terlarut di Perairan Karimunjawa Jawa Tengah. Jurnal Penelitian Sains, 13(1), 35-41.

Wijaya, D., A. F. Sentosa, \& D W. H. Tjahjo. (2012). Kajian kualitas perairan dan potensi produksi sumberdaya ikan di Danau Batur, Bali. Prosiding Seminar Nasional Lmnologi VI Tahun 2012: 386 399. Bali. 